\title{
Genetic Relationships among Species of Meretrix (Mollusca: Veneridae) in the Western Pacific Ocean ${ }^{1}$
}

\author{
Ayako Yashiki Yamakawa, ${ }^{2,3,6}$ Masashi Yamaguchi, ${ }^{4,5}$ and Hideyuki Imai ${ }^{4}$
}

\begin{abstract}
We compared allozymes at 12 loci in 12 populations of six species of Meretrix: M. lusoria (Japan, Korea, and Taiwan), M. petechialis (China and Korea), M. ovum (Thailand and Mozambique), M. lyrata (China), M. lamarckii (Japan), and Meretrix sp. A (Okinawa, Japan). Our allozyme results were generally consistent with the major groupings currently recognized within the genus based on morphological characters. However, we found two cryptic or undescribed species: Meretrix sp. A from Okinawa and M. cf. lusoria from Taiwan. The shell characters of Meretrix sp. A were similar to those of M. lamarckii, but the species was genetically distinct (Nei's genetic distance $D>0.845$ ) from all other species examined. The Taiwanese Meretrix population was morphologically indistinguishable from Japanese M. lusoria, although the genetic distance between the Taiwanese and Japanese populations showed a high degree of genetic differentiation $(D>0.386)$. Meretrix lusoria seedlings were introduced into Taiwan from Japan in the 1920s, and Japanese M. lusoria was previously thought to be established as a cultured stock. However, our results suggest that the Taiwanese population may represent a sibling or cryptic species of M. lusoria.
\end{abstract}

Asian hard clams, genus Meretrix (Veneridae), are commercially important bivalves in East and Southeast Asia and East Africa

\footnotetext{
${ }^{1}$ Financial support was provided from the $21 \mathrm{st}$ Century Center of Excellence (COE) Program of the University of the Ryukyus; the TaKaRa Harmonist Fund by the Takara Shuzo. Co., Ltd.; the Sasakawa Scientific Research Grant by The Japan Science Society; the Mikimoto Fund for Marine Ecology by the Mikimoto \& Co., Ltd.; and a research grant by the Interdisciplinary Research Institute of Environmental Sciences. Travel funding was provided from a graduate student research grant by the University of the Ryukyus Foundation. Manuscript accepted 4 September 2007.

${ }^{2}$ Graduate School of Engineering and Science, University of the Ryukyus, Nishihara, Okinawa, 903-0213, Japan.

${ }^{3}$ Department of Regional Economics and Environmental Policy, Okinawa International University, 2-6-1 Ginowan, Ginowan, Okinawa, 901-2701, Japan.

${ }^{4}$ Faculty of Science, University of the Ryukyus, Nishihara, Okinawa, 903-0213, Japan.

${ }^{5}$ Current address: 9658-2 Shiomi, Hyuga, Miyazaki 883-0033, Japan. .ac.jp).

${ }^{6}$ Corresponding author (e-mail: a.yamakawa@okiu
}

Pacific Science (2008), vol. 62, no. 3:385-394

(C) 2008 by University of Hawai'i Press

All rights reserved
(Yoosukh and Matsukuma 2001). These clams inhabit the tidal flats, estuaries, and sandy beaches of the Indian Ocean, including East Africa and Southeast Asia, and the western Pacific along the Chinese coast, Korean Peninsula, and Japanese Archipelago. The genus comprises nine recognized species: $M$. meretrix (Linnaeus, 1758), M. casta (Chemnitz, 1782), M. lusoria (Röding, 1798), M. petechialis (Lamarck, 1818), M. ovum (Hanley, 1845), M. planisulcata (Sowerby, 1851), M. lyrata (Sowerby, 1851), M. lamarckii Gray, 1853, and M. attenuata Dunker, 1862 (OBIS Indo-Pacific Molluscan Database 2006). Most are important fishery resources. People have eaten Asian hard clams since ancient times, and Meretrix shells are one of the most abundant mollusks found in shell middens in Japan and the Middle East (Kanamaru 1932, Charpentier et al. 2004).

Because of the economic importance of Meretrix, previous work has focused mainly on its aquaculture (Yoshida 1941, Wu and Liu 1992, Tuan and Phung 1998), organotin compounds (Midorikawa et al. 2004, Harino et al. 2006), and shellfish poisoning (Nguyen et al. 2006). Seedlings of a few Meretrix species are mass-produced, and nearly all hard 
clams in Taiwanese markets are cultured ( $\mathrm{Wu}$ and Liu 1989).

Past taxonomic studies of Meretrix considered only shell morphology (Fischer-Piette and Fischer 1940-1941, Yoosukh and Matsukuma 2001), although shell shape and color patterns often show marked intraspecific variability (Hamai 1934, 1935, Kosuge 2006). Systematic descriptions of Meretrix species are often confusing, and the specific name $M$. meretrix has apparently been used for various species (Yoosukh and Matsukuma 2001). Moreover, the shell form and color of $M$. lusoria and M. petechialis are very similar, leading to many erroneous identifications and notations in shell books, reports, and references.

Mitochondrial DNA (mtDNA) has been widely studied in several groups of animals, mainly for taxonomic and phylogenetic purposes. The advantages of using mtDNA include its simple maternal inheritance, absence of recombination, and high substitution rates (Wolstenholme 1992). However, a very high level of gender-associated mtDNA heteroplasmy has been detected in a few bivalve mollusks of the families Mytilidae, Unioidae, and Veneridae (Hoeh et al. 1996, Liu et al. 1996, Beagley et al. 1997, Passamonti and Scali 2001). Thus, the use of mtDNA to estimate evolutionary relationships in bivalves requires great care. Furthermore, the number of loci available for mtDNA analysis is limited. In contrast, allozyme analysis can include a number of loci coded in nuclear DNA simultaneously. Allozyme analysis remains an effective molecular tool with which to investigate phylogenetic relationships and has been much used in phylogenetic and population genetic studies of mollusks (Benzie and Williams 1998, Marins and Levy 1999, Ríos et al. 2002, Inness-Campbell et al. 2003, Väinölä 2003, Martínez et al. 2005, Zaslavskaya 2006).

Despite the economic importance of Meretrix, few phylogenetic and population genetic studies of the genus have been undertaken. Molecular techniques can aid in understanding the taxonomy and relationships within this genus. Therefore, we investigated the genetic relationships among
Meretrix species using electrophoretically detectable allozyme variation.

\section{MATERIALS AND METHODS}

\section{Samples}

A total of 12 local samples of Meretrix spp. was collected in East and Southeast Asia and East Africa in 2005. These clam samples were identified based on shell morphology and coloration. Individuals were sampled from the following locations: M. lusoria from Mutsu Bay (32 individuals examined) and Ariake Sea (30), Japan (MluJ-M and MluJ-A, respectively); $M$. cf. lusoria from Korea (32) and Taiwan (30) (McfK and McfT, respectively); $M$. petechialis from northern China (30) and Korea (31) (MpC and MpK, respectively); $M$. ovum from Mozambique (32) and Thailand (26) (MoM and MoT, respectively); $M$. lyrata from southern China (25) (MlyC); M. lamarckii from Miyagi (32) and Shimane (32), Japan (MlaJ-M and MlaJS, respectively); and Meretrix sp. A from Okinawa, Japan (23) (MspJ-O). The foot muscle and hepatopancreas were dissected from fresh specimens and immediately frozen at $-40^{\circ} \mathrm{C}$.

\section{Allozyme Electrophoresis}

Horizontal starch-gel electrophoresis was carried out based on the methods of Harris and Hopkinson (1976) and May et al. (1979). Tissue fragments were homogenized with sterilized distilled water. Hydrolyzed starch gels $(12.5 \%)$ were run at constant voltage. A total of 12 loci from 12 enzymes that showed adequate activity and resolution were routinely examined (Table 1). Terminology and notation of the allozymes were based on recommendations by Shaklee et al. (1990). Two buffer systems were assessed: the Tris-citrate pH 7.0 buffer system (CT-7; gel:buffer dilution $1: 10)$ was run at $250 \mathrm{~V}$ for $5 \mathrm{hr}$ for six enzymes, and the citrate- $\mathrm{N}$-(3-aminopropyl) morphoine $\mathrm{pH} 6.0$ buffer system (CAPM-6; gel:buffer dilution 1:4) was run at $250 \mathrm{~V}$ for $9 \mathrm{hr}$ for six enzymes. All zymograms were visualized using enzyme-specific stains following recipes in Numachi (1989). Alleles at 
TABLE 1

Resolved Enzymes, Most Effective Buffer Systems, and Tissues Used for Allozyme Analyses

\begin{tabular}{llllc}
\hline \hline Enzyme & Abbreviation & E.C. & Buffer & Tissue $^{b}$ \\
\hline Aspartate aminotranseferase & AAT & 2.6 .1 .1 & CAPM-6 & F \\
Aconitase hydrogenase & ACO & 4.2 .1 .3 & CAPM-6 & H \\
Catalase & CAT & 1.11 .1 .6 & CT-7 & H \\
Glyceraldehyde-3-phosphate dehydrogenase & GAPDH & 1.2 .1 .12 & CAPM-6 & F \\
Glucose-6-phosphate isomerase $^{a}$ Isocitrate dehydrogenase (NADP ${ }^{+}$) & GPI & 5.3 .1 .9 & CT-7 & F \\
Malate dehydrogenase & IDH & 1.1 .1 .42 & CT-7 & H \\
Malic enzyme (NADP $^{+}$) & MDH & 1.1 .1 .37 & CAPM-6 & F \\
Peptidase using leucyl-glycyl-glycine substrate & ME & 1.1 .1 .40 & CAPM-6 & F \\
6-Phosphogluconate dehydrogenase & PEP-lgg & $3.4 .11-13$ & CT-7 & H \\
Phosphoglucomutase & 6PGD & 1.1 .1 .44 & CT-7 & H \\
Superoxidase dismutase & PGM & 2.7 .5 .1 & CT-7 & F \\
\hline
\end{tabular}

${ }^{a}$ Enzyme commission number.

${ }^{b} \mathrm{~F}$, foot; $\mathrm{H}$, hepatopancreas.

each locus were labeled alphabetically in order of the relative electrophoretic mobility of the allozymes.

\section{Data Analysis}

Genotype and allele frequencies for the 12 loci were determined for all local samples. Genotype frequencies at polymorphic loci were examined for agreement with the expectations of Hardy-Weinberg equilibrium using a chi-square test. The mean biased estimate of expected heterozygosity $\left(H_{e}\right)$, mean observed heterozygosity $\left(H_{o}\right)$, and percentage of polymorphic loci $(P)$ within samples, as well as Nei's (1978) unbiased measures of genetic identity $(I)$ and genetic distance $(D)$ between samples, were calculated using POPGENE v. 1.32 (Yeh et al. 1999). The unweighted paired group method of cluster analysis (UPGMA [Sokal and Sneath 1963]) was used to construct a phylogenetic tree.

\section{RESULTS}

Allele frequencies at the 12 polymorphic loci and average measures of genetic variation of all samples are presented in Table 2. The levels of genetic variation differed considerably among the samples, with average expected heterozygosity $(\mathrm{He})$ varying from 0.090 to 0.375 (Table 2). Several interspecific diagnostic alleles were observed: allele $\mathrm{F}$ and $\mathrm{G}$ at the $A C O$ locus in $M$. ovum, allele A at the GPI locus in M. lyrata, the combination of allele $\mathrm{A}$ and $\mathrm{C}$ at the $\mathrm{MDH}-2$ locus and allele B and C at the SOD-2 locus in M. lamarckii, and the combination of allele $\mathrm{A}$ at the $I D H$ locus and allele $\mathrm{C}$ at the $M D H-2$ locus in Meretrix sp. A (Table 2). However, no diagnostic alleles were observed for $M$. lusoria, M. cf. lusoria, or M. petechialis.

Unbiased genetic identities (I) (Nei 1978) between taxa varied from 0.162 between MluJ-A and MoT to 0.850 between McfK and MpK (Table 3). Genetic identities between separated conspecific populations within taxa were 0.970 (MluJ-M and MluJ-A), 0.976 ( $\mathrm{MpC}$ and $\mathrm{MpK}$ ), 0.818 (MoT and $\mathrm{MoM}$ ), and 0.949 (MlaJ-S and MlaJ-O). Intraspecific identities were generally higher than interspecific identities (Figure 1). However, two modes of interspecific genetic identity were clear: $0.25-0.3$ and $0.8-0.85$. The genetic identities between $M$. lusoria, $M$. cf. lusoria, and $M$. petechialis were quite high, averaging 0.783 , indicating that these species are closely related.

Nei's unbiased genetic distance $(D)$ between taxa ranged from 0.163 between McfK and $\mathrm{MpK}$ to 1.819 between MluJ-A and MoT (Table 3). The lowest $D$ for all pairwise population comparisons were within taxa: 0.030 between MluJ-M and MluJ-A, 0.025 between 


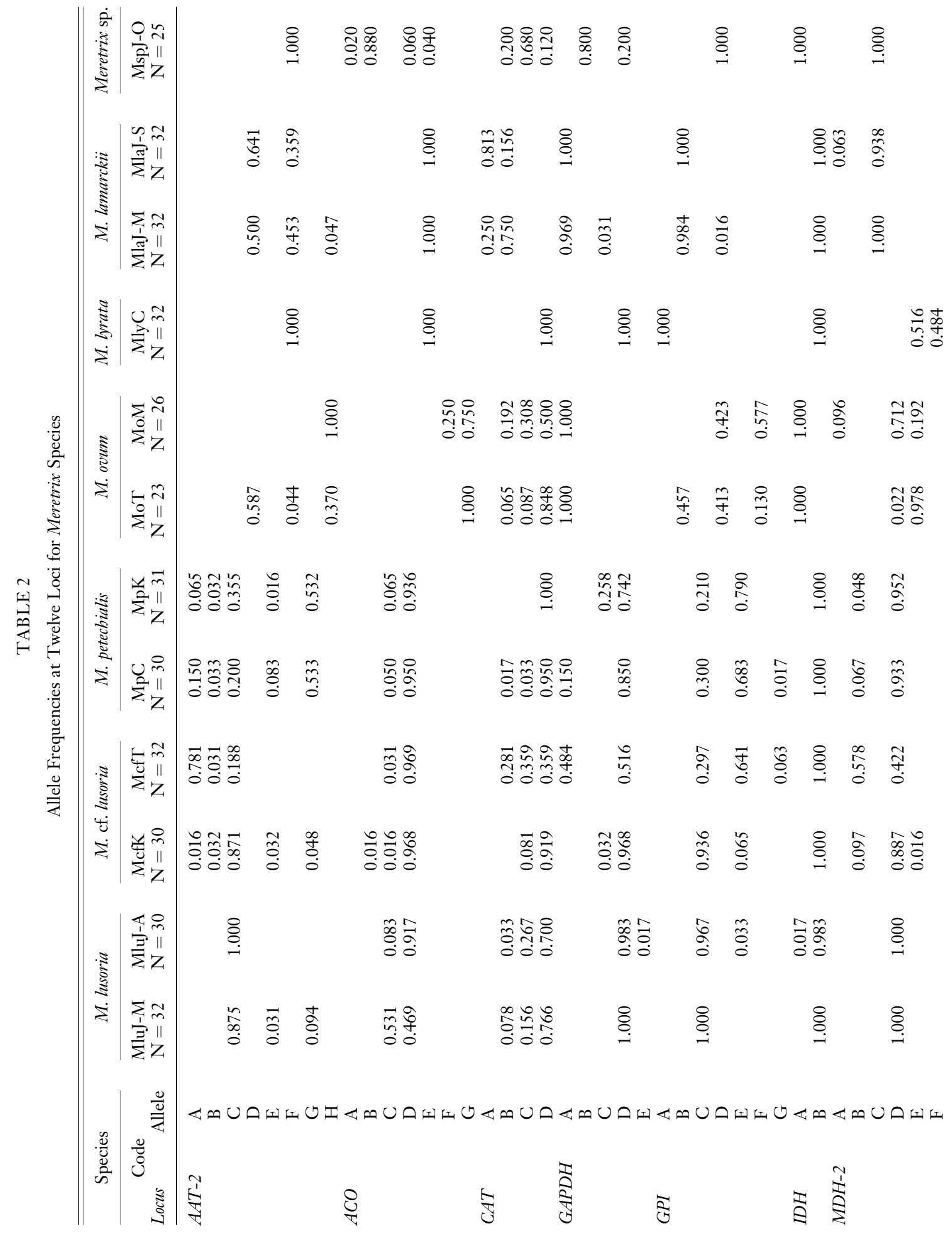




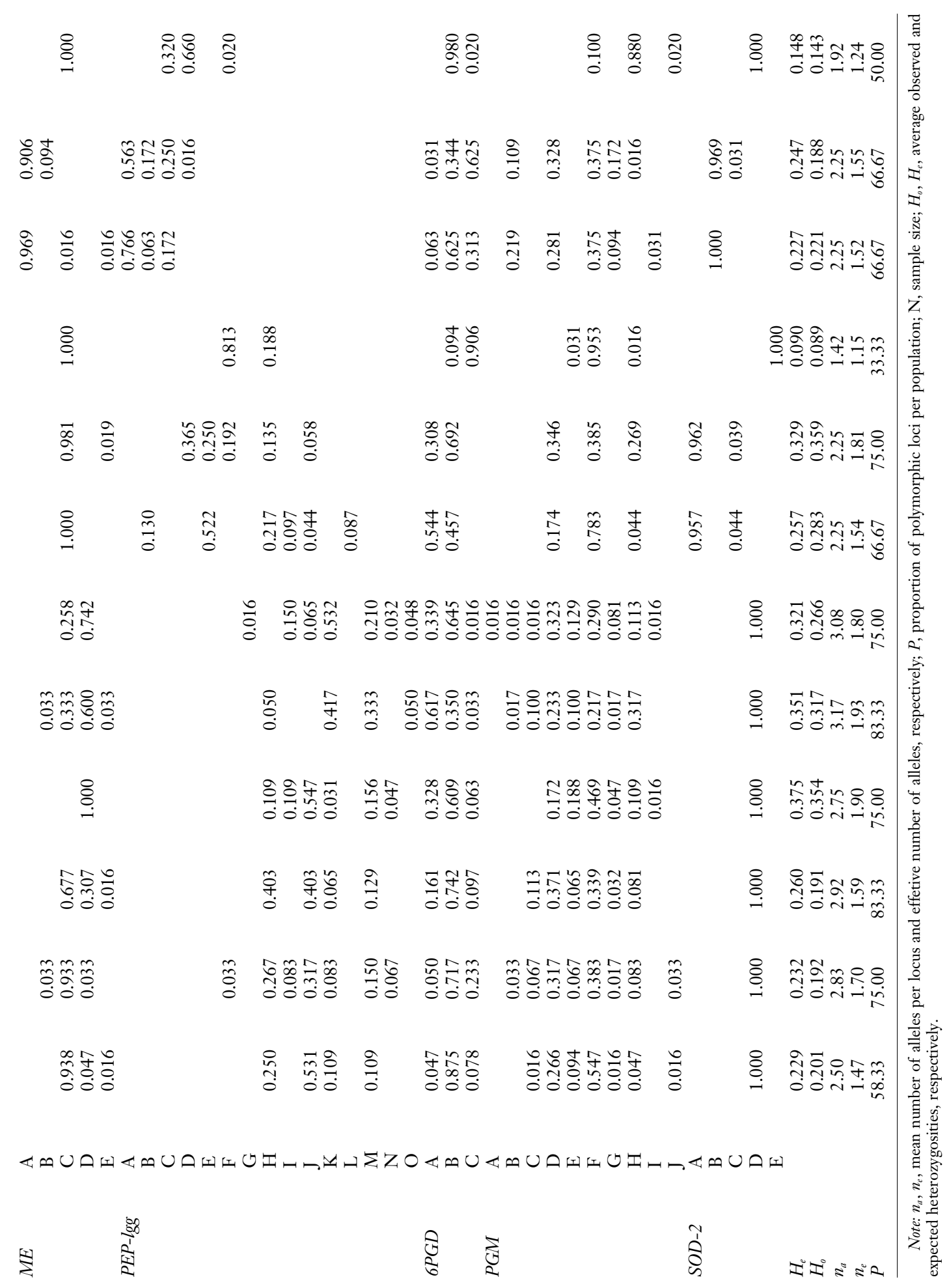


TABLE 3

Matrix of Nei's Genetic Identity ( $I$, above Diagonal) and Genetic Distance ( $D$, below Diagonal) among 12 Populations of Meretrix Species Based on 12 Allozyme Loci

\begin{tabular}{|c|c|c|c|c|c|c|c|c|c|c|c|c|}
\hline \multirow{3}{*}{$\begin{array}{l}\text { Genus } \\
\text { Species } \\
\text { Code }\end{array}$} & \multicolumn{12}{|c|}{ Meretrix } \\
\hline & \multicolumn{2}{|c|}{ lusoria } & \multicolumn{2}{|c|}{ cf. lusoria } & \multicolumn{2}{|c|}{ petechialis } & \multicolumn{2}{|c|}{ ovum } & \multirow{2}{*}{$\frac{\text { lyrata }}{\text { MlyC }}$} & \multicolumn{2}{|c|}{ lamarckii } & \multirow{2}{*}{$\frac{\text { sp. }}{\text { MspJ-O }}$} \\
\hline & MluJ-M & MluJ-A & McfK & McfT & $\mathrm{MpC}$ & $\mathrm{MpK}$ & MoT & MoM & & MlaJ-M & MlaJ-S & \\
\hline MluJ-M & & 0.970 & 0.888 & 0.652 & 0.729 & 0.745 & 0.188 & 0.254 & 0.351 & 0.206 & 0.191 & 0.251 \\
\hline MluJ-A & 0.030 & & 0.911 & 0.674 & 0.760 & 0.764 & 0.162 & 0.237 & 0.341 & 0.191 & 0.189 & 0.246 \\
\hline McfK & 0.119 & 0.093 & & 0.741 & 0.845 & 0.850 & 0.265 & 0.320 & 0.419 & 0.192 & 0.176 & 0.308 \\
\hline Mcf T & 0.427 & 0.395 & 0.299 & & 0.809 & 0.808 & 0.214 & 0.259 & 0.272 & 0.278 & 0.246 & 0.256 \\
\hline $\mathrm{MpC}$ & 0.316 & 0.275 & 0.168 & 0.212 & & 0.976 & 0.244 & 0.292 & 0.370 & 0.186 & 0.176 & 0.262 \\
\hline MpK & 0.295 & 0.269 & 0.163 & 0.213 & 0.025 & & 0.222 & 0.276 & 0.355 & 0.190 & 0.171 & 0.256 \\
\hline MoT & 1.670 & 1.819 & 1.329 & 1.544 & 1.410 & 1.506 & $\gamma_{0}$ & 0.818 & 0.326 & 0.273 & 0.267 & 0.334 \\
\hline MoM & 1.369 & 1.439 & 1.140 & 1.351 & 1.230 & 1.288 & 0.201 & 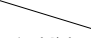 & 0.234 & 0.216 & 0.181 & 0.430 \\
\hline MlyC & 1.046 & 1.077 & 0.870 & 1.304 & 0.994 & 1.035 & 1.120 & 1.454 & & 0.314 & 0.333 & 0.245 \\
\hline MlaJ-M & 1.579 & 1.653 & 1.648 & 1.279 & 1.684 & 1.663 & 1.298 & 1.531 & 1.157 & & 0.949 & 0.244 \\
\hline MlaJ-S & 1.658 & 1.667 & 1.740 & 1.404 & 1.736 & 1.764 & 1.319 & 1.711 & 1.099 & 0.053 & & 0.193 \\
\hline MspJ-O & 1.384 & 1.402 & 1.177 & 1.364 & 1.340 & 1.362 & 1.098 & 0.845 & 1.405 & 1.409 & 1.645 & \\
\hline
\end{tabular}

$\mathrm{MpC}$ and $\mathrm{MpK}, 0.201$ between $\mathrm{MoT}$ and MoM, and 0.053 between MlaJ-M and MlaJ$\mathrm{S}$. In the UPGMA tree based on genetic distance (Figure 2), M. lamarckii (MlaJ-M and $\mathrm{MlaJ}-\mathrm{S})$ was the first to diverge from other Meretrix species. Meretrix sp. A (MspJ-O) clustered with $M$. ovum (MoT and MoM), and $M$. lyrata (MlyC) was within a cluster

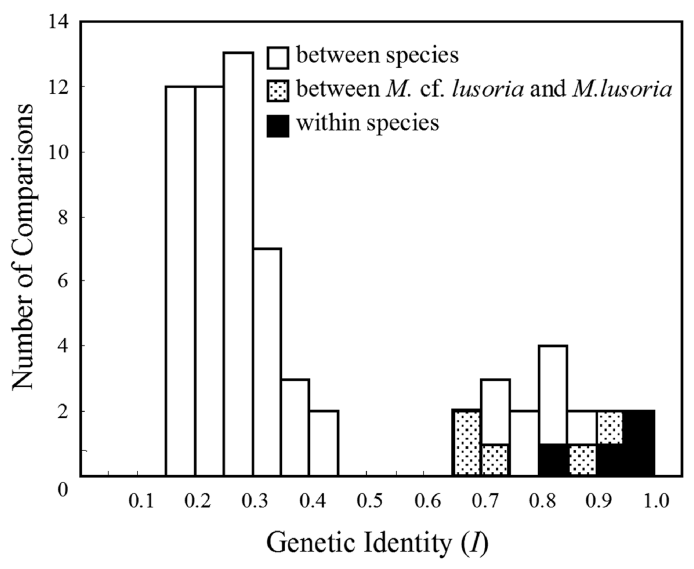

Figure 1. Frequency distribution of genetic identity $(I)$ based on 12 allozyme loci within species (i.e., M. lusoria, $M$. ovum, and $M$. lamarckii), between $M$. cf. lusoria and M. lusoria, and between Meretrix species. containing $M$. lusoria, M. cf. lusoria, and $M$. petechialis. The Korean M. cf. lusoria McfK population joined with the M. lusoria (MluJ$M$ and MluJ-A) cluster, with $D$ of 0.119 between McfK and MluJ-M and D of 0.093 between McfK and MluJ-A. In contrast, the Taiwanese $M$. cf. lusoria McfT population joined the $M$. petechialis ( $\mathrm{MpC}$ and $\mathrm{MpK}$ ) cluster. The $D$ between $M c f T$ and $\mathrm{MpC}$ was 0.212 and that between Mcf T and MpK was

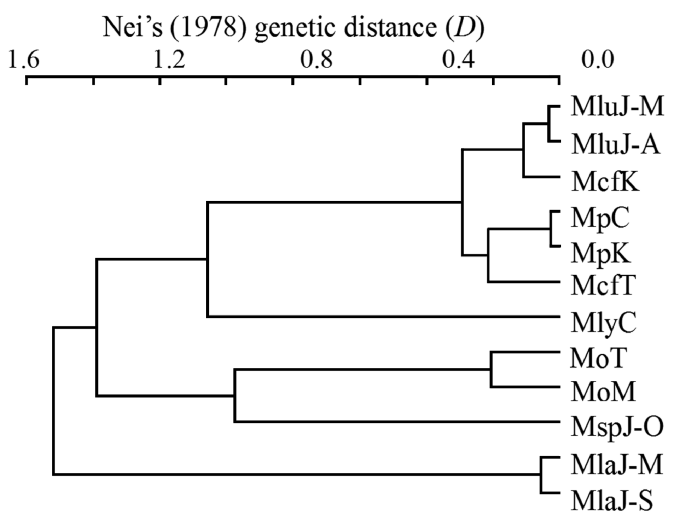

Figure 2. UPGMA tree of Nei's (1978) genetic distance, showing the genetic relationships among 12 populations of Meretrix species based on 12 allozyme loci. 
0.213. Within the genus Meretrix, M. lusoria and $M$. petechialis were the most closely related species, with a small genetic distance $(D<0.316)$.

\section{DISCUSSION}

The results of our allozyme analysis were largely consistent with the major groupings currently recognized within the genus Meretrix based on morphological characters, except for two species: Meretrix sp. A (MspJO) from Okinawa and M. cf. lusoria from Taiwan (McfT) (Figure 2). Meretrix sp. A (MspJ-O) is a sister taxon to M. ovum, although its shell morphology and habitat preference are similar to those of $M$. lamarckii; indeed, Kosuge (2003) identified the Okinawan species as $M$. lamarckii. Both species prefer dissipative sandy beaches facing highsalinity open seas and share similar morphological adaptations such as a relatively rectilinear ventral margin and a deeper pallial sinus than M. lusoria, M. petechialis, M. lyrata, and M. ovum. However, the genetic data indicated a marked difference in that Meretrix sp. A (MspJ-O) was genetically distant from all the other species examined $(D>0.845)$. Because this species does not, to our knowledge, morphologically or genetically match any other known species, it may be an undescribed Meretrix species.

Meretrix lusoria seedlings were introduced to Taiwan from Japan in 1925 and have spread widely in many sandy beaches and estuaries on the west coast of Taiwan (Chen 1984, Chien and Hsu 2006). Hard-clam aquaculture expanded rapidly, with the percentage of aquaculture-produced clams on the market reaching $98.8 \%$ in 1986 (Wu and Liu 1989). Introduced Japanese $M$. lusoria was assumed to have been established as a cultured stock in Taiwan, and cultured hard clams were thought to be an introduced species. However, the Taiwanese population (McfT) shows a high degree of differentiation $(D>0.395$ [Table 3]) from Japanese M. lusoria populations (MluJ-M and MluJ-A [Figure 2]). At the $A A T-2, G A P D H, G P I$, and $M e$ loci, Japanese $M$. lusoria populations and Taiwanese M. cf. lusoria showed limited allele

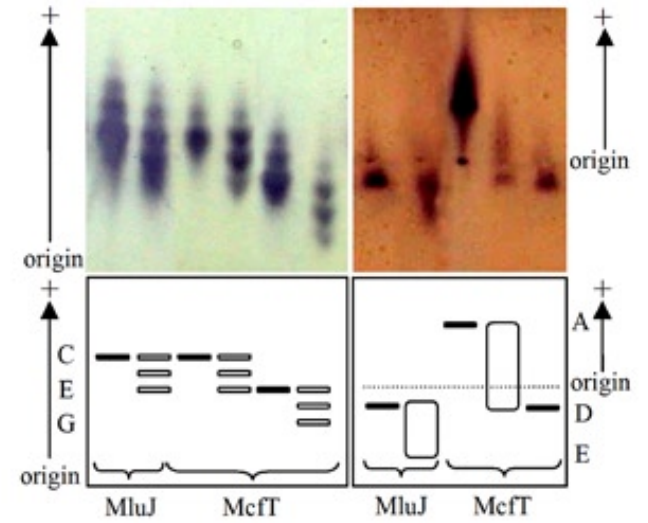

FIGURE 3. Electrophoretic patterns of Japanese M. lusoria (MluJ-M and MluJ-A) and Taiwanese $M$. cf. lusoria (McfT). Left: GPI locus (Dimer). Right: GAPDH locus (Tetramer).

frequency overlap (3-50\% [Table 2 and Figure 3]). This suggests that McfT and $M$. lusoria may be different species. The shell morphology and coloration of M. lusoria and the Taiwanese population (McfT) do not differ clearly, suggesting that the Taiwanese population may be a cryptic species of $M$. lusoria. Our results suggest that a local Taiwanese Meretrix existed before the introduction of Japanese M. lusoria in 1925 and that Japanese $M$. lusoria might have failed to survive as a cultured stock because of habitat or climate differences.

Within the genus Meretrix, M. lusoria and $M$. petechialis were the most closely related, with small genetic distances $(D<0.316$ [Table 3]). In line with this genetic closeness, $M$. lusoria and $M$. petechialis are similar in morphological characters and are occasionally confused in illustrated books and references.

Some Korean M. cf. lusoria (McfK) individuals showed morphological characteristics of both M. lusoria and M. petechialis. Nevertheless, our genetic data indicate that Korean McfK belongs to M. lusoria. In the Asian continent, the habitat of M. lusoria is limited to the southern part of the Korean Peninsula (Yamashita et al. 2004), whereas M. petechialis occurs from the west coast of the Korean Peninsula to southern China and Vietnam. 
The habitat preferences of M. lusoria and $M$. petechialis appear very similar: both occur in sandy and muddy tidal flats in estuarine environments of inland seas. In South Korea, the natural distribution of $M$. lusoria and $M$. petechialis is allopatric, which probably maintains reproductive isolation between these two species.

In Japan, $M$. petechialis seedlings imported from the Asian continent have been released into the natural habitat of M. lusoria since the 1990s (Japanese Ministry of the Environment 2005). If the reproductive isolation of M. lusoria and M. petechialis was not complete, hybridization between these two species could occur because of the artificial sympatric distribution in Japan. Kawase (2002) claimed that hybrids between the local M. lusoria and introduced $M$. petechialis, diagnosed by morphological characters, were found in Aichi Prefecture, Japan. Further investigation using DNA is needed to confirm the existence of hybrid individuals.

We analyzed two unknown Meretrix species (i.e., McfT and MspJ-O) in addition to five of the nine described species (i.e., $M$. $l u$ soria, M. petechialis, M. ovum, M. lyrata, and M. lamarckii). Future combined morphological and genetic investigations may reveal additional undescribed Meretrix species.

Meretrix species are distributed broadly in the West Pacific, Asia, and the Indian Ocean. The center of origin of Meretrix seems to be located in the Indo-Malayan subregion of the Indo-West Pacific. Meretrix ovum is widely distributed compared with other Meretrix species: it inhabits muddy bottoms from the Mekong River in Vietnam and Gulf of Thailand (Yoosukh and Matsukuma 2001) to Mozambique. We hypothesize that the ancestral species of Meretrix may be closely related to M. ovum and may have dispersed in two directions (i.e., west and northeast) from the Indo-Malayan subregion by means of larval dispersal along strong ocean currents. During the process of spreading, the ancestral species may have diverged into two major types (i.e., mud-flat species in estuarine environments and sandy-beach species in open sea areas). Further studies that include the species not examined here and use genetic sequence data, particularly from DNA, may resolve these phylogeographic issues.

\section{ACKNOWLEDGMENTS}

We are grateful to Prof. T. Y. Shy and Ms. K. Lee, National Penghu University; Mr. J. Y. Kao, Noah's Ark Ecological Engineering Consultant Co., Ltd., Taiwan; Mr. A. Endo, Ichi Lda., Mozambique and Ms. S. Toda, Japan International Cooperation Center; and A. Inouye and S. Lee, University of the Ryukyus, for their help in collecting samples. We also thank Dr. H. Saito, National Science Museum; Dr. B. Metivier, Muséum National d'Histoire Naturelle; and Dr. Y. Finet, $\mathrm{Mu}-$ séum d'Histoire Naturelle de la Ville de Genève, for their support in observing Meretrix specimens in museum collections. Our heartfelt thanks go to Dr. K. Numachi for editorial comments. Finally, we thank Prof. Y. Ikeda, Prof. S. Suda, Mr. T. Yoshino, Dr. K. Tachihara, and all of our laboratory members at the University of the Ryukyus for their help and comments.

\section{Literature Cited}

Beagley, C. T., K. A. Taylor, and D. R. Wolstenholme. 1997. Gender-associated diverse mitochondrial DNA molecules of the mussel Mytilus californianus. Curr. Genet. 31:318-324.

Benzie, J. A. H., and S. T. Williams. 1998. Phylogenetic relationships among giant clam species (Mollusca: Tridacnidae) determined by protein electrophoresis. Mar. Biol. (Berl.) 132:123-133.

Charpentier, V., S. Méry, and C. Phillips. 2004. Des coquillages ... outillages des Ichtyophages? Mise en évidence d'industries sur Veneridae, du Néolithique à l'âge du Fer (Yémen, Oman, E.A.U). Arab. Arch. Epig. 15:1-10 [in French with English abstract].

Chen, H. C. 1984. Recent innovations in cultivation of edible molluscs in Taiwan, with special reference to the small abalone $\mathrm{Hal}$ iotis diversicolor and the hard clam Meretrix lusoria. Aquaculture 39:11-27.

Chien, Y. H., and W. H. Hsu. 2006. Effects of diets, their concentrations and clam size 
on filtration rate of hard clams (Meretrix lusoria). J. Shellfish Res. 25:15-22.

Fischer-Piette, E., and P. H. Fischer. 19401941. Révision des espèces vivantes de Meretrix s. s. du Muséum National d'Histoire Naturelle. J. Conchyliol. 84:313-345 [in French].

Hamai, I. 1934. On the local variation in the shells of Meretrix meretrix (L.), with special reference to growth of organism. Sci. Rep. Tohoku Imp. Univ. Biol. 9:131-158.

. 1935. A study of one case in which different environmental conditions produce different types of Meretrix meretrix. Sci. Rep. Tohoku Imp. Univ. Biol. 10:485-498.

Harino, H., S. Midorikawa, T. Arai, M. Ohji, N. D. Cu, and N. Miyazaki. 2006. Concentrations of booster biocides in sediment and clams from Vietnam. J. Mar. Biol. Assoc. U. K. 86:1163-1170.

Harris, H., and D. A. Hopkinson. 1976. Handbook of enzyme electrophoresis in human genetics. North-Holland, Amsterdam.

Hoeh, W. R., D. T. Stewart, B. W. Sutherland, and E. Zouros. 1996. Multiple origins of gender-associated mitochondrial DNA lineages in bivalves (Mollusca: Bivalvia). Evolution 50:2276-2286.

Inness-Campbell, J., M. Stuckey, and M. S. Johnson. 2003. Allozymic investigation of phylogeny of Littoraria (Gastropoda: Littorinidae). J. Molluscan Stud. 69:19-26.

Japanese Ministry of the Environment. 2005. Information on Meretrix petechialis. Wildlife Division, Nature Conservation Bureau (http://www.env.go.jp/nature/intro/ 1outline/caution/detail_mu.html\#11).

Kanamaru, T. 1932. Japanese hard clam story in Ise. Venus 3 (3): 144-154 [in Japanese].

Kawase, M. 2002. Macrobenthic organisms in the estuary of the Yahagi River. Yahagigawakenkyu 6:81-98 [in Japanese].

Kosuge, T. 2003. Occurrence of Meretrix lamarckii Deshayes (Mollusca, Bivalvia, Veneridae) at a sandy beach near the mouth of Urauchi River, Iriomote Island, Okinawa, Japan. Nankiseibutsu 45 (2): 128-131 [in Japanese].

- 2006. Notes on the lyrate hard clam
Meretrix sp. (Bivalvia: Veneridae) in Vietnam, with special reference to its introduction to the northern coasts of Vietnam. Chiribotan 36 (4): 132-135 [in Japanese].

Liu, H., J. B. Mitton, and S. Wu. 1996. Paternal mitochondrial DNA differentiation far exceeds maternal mitochondrial DNA and allozyme differentiation in the freshwater mussel, Anodonta grandis. Evolution 50:952-957.

Marins, L. F., and J. A. Levy. 1999. High genetic distance between marine bivalves of the genus Mesodesma inhabiting the Atlantic and Pacific coasts of South America. Comp. Biochem. Physiol. A Comp. Physiol. 124:313-319.

Martínez, P., M. Pérez-Losada, A. Guerra, and A. Sanjuan. 2005. First genetic variation and diagnosis of the short-finned squid species of the genus Illex (Cephalopoda: Ommastrephidae). Mar. Biol. (Berl.) 148:97-108.

May, B., J. E. Wright, and M. Stoneking. 1979. Joint segregation of biochemical loci in Salmonidae: Results from experiments with Salvelinus and review of the literature on other species. J. Fish. Res. Board Can. 36:1114-1128.

Midorikawa, S., T. Arai, H. Harino, N. D. $\mathrm{Cu}, \mathrm{P}$. A. Duc, and N. Miyazaki. 2004. Organotin levels in bivalves in Southeast Asia. Coastal Mar. Sci. 29 (1): 57-62.

Nei, M. 1978. Estimation of average heterozygosity and genetic distance from a small number of individuals. Genetics 89:583590.

Nguyen, V. N., D. V. Ha, and L. T. Tung. 2006. Dinophysis spp. recorded in the coastal waters of northern Vietnam during 2002-2003. Coastal Mar. Sci. 30 (1): 107110.

Numachi, K. 1989. Population differentiation of marine organisms by isozyme analysis. Pages 42-63 in Japan Fisheries Conservation Association, ed. Report on the genetic assessment project. Japan Fisheries Resource Conservation Association, Tokyo [in Japanese].

OBIS Indo-Pacific Molluscan Database. 2006. (http://data.acnatsci.org/obis/find_ mollusk.html). 
Passamonti, M., and V. Scali. 2001. Genderassociated mitochondrial DNA heteroplasmy in the venerid clam Tapes philippinarum (Mollusca: Bivalvia). Curr. Genet. 39:117-124.

Ríos, C., S. Sanz, C. Saavedra, and J. B. Pena. 2002. Allozyme variation in populations of scallops, Pecten jacobaeus (L.) and P. maxi$m u s$ (L.) (Bivalvia: Pectinidae), across the Almeria-Oran front. J. Exp. Mar. Biol. Ecol. 267:223-244.

Shaklee, J. B., F. W. Allendorf, D. C. Morizot, and G. S. Whitt. 1990. Gene nomenclature for protein-coding loci in fish. Trans. Am. Fish. Soc. 119:2-15.

Sokal, R. R., and P. H. A. Sneath. 1963. Principles of numerical taxonomy. Freeman, San Francisco.

Tuan, V. S., and N. H. Phung. 1998. Status of bivalve exploitation and farming in the coastal waters of South Vietnam. Spec. Publ. Phuket Mar. Biol. Cent. 18 (1): 171-174.

Väinölä, R. 2003. Repeated trans-Arctic invasions in littoral bivalves: Molecular zoogeography of the Macoma balthica complex. Mar. Biol. (Berl.) 143:935-946.

Wolstenholme, D. R. 1992. Animal mitochondrial DNA: Structure and evolution. Int. Rev. Cytol. 141:173-216.

Wu, W. L., and H. P. Liu. 1989. Malacological research on Meretrix resources in Tai- wan II. History review and evaluation on the studies of the Taiwan Meretrix. Bull. Malacol. Rep. China 14:49-61 [in Chinese with English abstract].

1992. Developmental rhythm on gamete and gonad of Meretrix lusoria from Taiwan (Bivalvia: Veneridae). Bull. Malacol. Rep. China 17:79-86 [in Chinese with English abstract].

Yamashita, H., S. Sato, K. W. Kim, Y. Henmi, H. Nagata, S. Yamamoto, A. Ikeguchi, Y. Mizuma, J. Nawa, and R. Takashima. 2004. The silent mud flat. Report of the Takagi Fund for Citizen Science 1:85-91 [in Japanese].

Yeh, F. C., R. C. Yang, T. Boyle, Z. H. Ye, and J. X. Mao. 1999. POPGENE, version 1.31 , the user-friendly shareware for population genetic analysis. Molecular Biology and Biotechnology Centre, University of Alberta, Canada.

Yoosukh, W., and A. Matsukuma. 2001. Taxonomic study on Meretrix (Mollusca: Bivalvia) from Thailand. Spec. Publ. Phuket Mar. Biol. Cent. 25 (2): 451-460.

Yoshida, H. 1941. Notes on the early lifehistory of Meretrix meretrix. Venus 11 (1): 1-11 [in Japanese with English summary]. Zaslavskaya, N. I. 2006. Allozyme comparison of Littorina species from the northwestern Pacific. J. Molluscan Stud. 72:163-166. 